\title{
Penerapan Kebijakan Penghapusan Sanksi Administrasi Pajak Kendaraan Bermotor di Kota Jakarta Selatan Tahun 2019
}

\author{
Bhakti Nur Avianto ${ }^{1, *}$, Muhammad Hasbi ${ }^{2}$ \\ ${ }^{1,2}$ FISIP Administrasi Publik, Universitas Nasional, Jakarta Selatan, Indonesia \\ ${ }^{1}$ bhakti.nur.avianto@ civitas.unas.ac.id.*; ${ }^{2}$ hasbimuhammad96@ gmail.com \\ * corresponding author
}

\section{ARTICLE INFO}

\section{Article history}

Received 2020-03-27

Revised 2020-06-05

Accepted 2020-06-22

Keywords

Kebijakan, Sanksi Administrasi,

Pemutihan, Animo

\begin{abstract}
The Provincial Government of DKI Jakarta issued Governor Regulation Number 3 of 2018 concerning the elimination of tax administration sanctions (sunset policy) or better known to the public by bleaching. The end of 2019 there were still PKB and BBN arrears, particularly in the South Jakarta City area reaching 15 billion. The results showed the realization of motor vehicle tax revenue of $R p$ $115,917,771,730$, - there was a reduction of $R p$ 108,247,742,466, meaning there were still motor vehicle tax arrears of around 7.5 billion. This problem arises because the socialization of bleaching information is still not optimal, the low public interest in the program, and the low tax compliance.

This statement emerged from the results of a survey of respondents who stated that the responsive attitude to the sunset policy reached $88.5 \%$, of which $47.9 \%$ stated the respondents agreed to the policy of eliminating motor vehicle administration sanctions but they had not used it, in other words, the sunset policy make public interest to obey pay taxes increases. So that the important role of the DKI Jakarta Regional Tax and Retribution Agency (BPRD) will immediately improve tax administration, improve services, systematically and continuously educate taxpayers and ensure law enforcement.
\end{abstract}

\section{PENDAHULUAN}

Potensi pendapatan dari sektor pajak di DKI Jakarta berkontribusi besar terhadap pembiayaan pembangunan infrastruktur terutama dari sektor pajak kendaraan bermotor. Jumlah masyarakat yang begitu besar menyebabkan penggunaan kendaraan bermotor di Jakarta meningkat pesat, sebagaimana data Badan Pusat Statistik di Tahun 2019 menunjukan pengguna kendaraan bermotor roda dua jumlahnya mencapai 13,9 juta kendaraan sedangkan roda empat sebanyak 3,5 juta kendaraan. Data tersebut menunjukan bahwa jumlah kendaraan bermotor di Jakarta jauh lebih banyak dari pada jumlah penduduknya. Melalui pendataan dari Badan Pajak dan Retribusi Daerah (BPRD) DKI Jakarta mencatat di Tahun 2017 dari 13,9 juta kendaraan masih ada tunggakan pajak BBN-KB sebesar 242.070.010 juta; PKB sebesar 79.063.988.054 milyar; di Tahun 2018 tunggakan pajak BBN-KB sebesar 101.700.000 juta; PKB sebesar 90.658.276.707 milyar. Badan pajak tersebut memprediksi dari 3,1 juta kendaraan roda dua dan sekitar 748,5 Ribu unit mobil yang menunggak pembayaran pajaknya, jika di total tunggakan pajak tersebut mencapai angka 1,18 triliun.

Dari uraian tersebut dapat dilihat tunggakan pajak dari sektor PKB menunjukan angka yang cukup besar sehingga pemerintah provinsi DKI Jakarta dituntut untuk menggali potensi pajak melalui kebijakan penghapusan sanksi administrasi yang diharapkan dapat membantu dan mempercepat penerimaan daerah. Salah satu potensi tunggakan pajak kendaraan bermotor terbesar berada di wilayah Kota Jakarta Selatan, dimana wilayah ini sebagai salah satu kota di provinsi DKI Jakarta dengan jumlah penduduknya yang sangat padat, di mana berbagai macam permasalahan yang kompleks terjadi di dalamnya terutama masalah transportasi dan kepemilikan kendaraan bermotor yang jumlah pertumbuhannya sangat pesat dan berbanding terbalik terhadap kesadaran para penggunanya yang belum menaati kewajiban untuk membayar kewajibannya (Syafitri, 2016). Selain itu, setiap tahun jumlah pertumbuhan kendaraan bermotor khususnya kendaraan pribadi mobil dan sepeda motor yang menjadi pilihan moda transportasi pribadi terpadat di Jakarta. 
Kebijakan fiskal khususnya di bidang retribusi pajak transportasi dapat menjadi kontribusi besar bagi permasukan daerah khususnya Pendapatan Asli Daerah (PAD), yang dapat membantu membiayai kebutuhan pemerintahan daerah. Pengelolaan keuangan daerah sangat erat hubungannya dengan manajemen oraganisasi dimana pemerintah daerah di tuntut untuk dapat mengelola keuangannya sendiri secara mandiri tanpa harus membebani pemerintah pusat (Fattah dan Imran, 2009). Bahkan setelah adanya perubahan Undang-Undang perpajakan yaitu pengesahan UU No. 16 Tahun 2009 yang merupakan Perubahan Terakhir Atas Undang-Undang No. 6 Tahun 1983 tentang Ketentuan Umum dan Tata Cara Perpajakan (KUP) yaitu diatur dalam pasal 19 ayat (1), Menteri Keuangan Republik Indonesia mengeluarkan kebijakan penghapusan sanksi pajak yang lebih dikenal dengan sebutan Sunset Policy Jilid II. Dalam kebijakan ini, unsur sebagai Tax Amnesty lebih dominan yang dimana sifatnya sebagai pengampunan pajak yang diberikan pemerintah ke seluruh warga negara, dengan harapan masyarakat mendaftarkan diri sebagai wajib pajak.

Beberapa penelitian yang telah dilakukan berkaitan dengan penghapusan pajak, Prananjaya (2018) kepatuhan pajak dapat dicapai dengan lebih efektif ketika program tax amnesty dikombinasikan dengan sanksi pajak yang rendah, sehingga mengimplikasikan pendekatan motivasional berupa insentif akan lebih efektif jika dikombinasikan dengan pendekatan motivasional berupa ancaman yang berlevel rendah (low enforcement). Sanski perpajakan merupakan salah satu upaya yang digunakan pemerintah untuk meningkatkan kepatuhan pajak. Menurut Ali, Cecil, dan Knoblett (2001), sanksi perpajakan merupakan suatu kebijakan yang sangat efektif untuk mencegah ketidakpatuhan Wajib Pajak karena sanksi pajak akan membuat para Wajib Pajak menjadi lebih patuh dan memberikan efek jera kepada Wajib Pajak yang melanggar atau tidak mematuhi peraturan perpajakan yang berlaku. Pemerintah telah mengambil langkah kebijakan yang bersifat persuasif (Adiyanta, 2018). Kebijakan perpajakan yang bersifat lunak dituangkan dalam bentuk kebijakan pengampunan pajak (tax amnesty) dan yang secara khusus lebih dikenal dalam bentuk kebijakan penghapusan sanksi administrasi perpajakan ini merupakan amanat Pasal 37A UU No. 28 Tahun 2007 tentang Ketentuan Umum dan Tata Cara Perpajakan (KUP). Kebijakan penghapusan pajak (tax amnesty) ini adalah penghapusan pembayaran pajak hanya sebagian dari keseluruhan kewajiban pajak, yakni atas sanksi pajaknya. Hasil penelitian lainnya yang relevan diangkat oleh Sunarta (2017) dalam mensosialisasikan peraturan tersebut melalui media, baik media cetak seperti majalah dan koran tempo maupun melalui siaran televisi seperti Metro TV dan radio RRI. Ketersediaan sumber daya yang terdapat di kantor pajak sangat terbatas mengingat bahwa para pegawai tidak hanya harus memiliki perilaku yang baik namun bisa dipertimbangkan dari segi kualitas dan kemampuannya. Keberhasilan efektivitas kerja pegawai dipengaruhi oleh kuatnya komitmenseluruh jajaran. Selain itu, perpaduan penerapan kebijakan yang disertai dengan etika manajemen yang sesuai dengan syariah membantu dalam memaksimalkan pelaksanaannya.

Berdasarkan uraian tersebut di atas, tersirat suatu pertanyaan bagaimana penerapan penghapusan pajak kendaraan bermotor? Apa alasan yang mendasari adanya kebijakan penghapusan penghapusan sanksi administrasi perpajakan yang dilakukan oleh pemerintah? Dan apa yang menjadi tujuan dibentuknya penghapusan pajak kendaraan bermotor di Kota Jakarta Selatan? Pertanyaan ini muncul disebabkan masih belum terealisasinya program pemutihan pajak dari pengguna kendaraan roda dua maupun roda empat dalam memenuhi target pajak yang dikelola oleh Badan Pajak dan Retribusi Daerah (BPRD) Provinsi DKI Jakarta, sosialisasi terhadap wajib pajak masih rendah, razia pengesahan STNK belum efektif, disamping masih kurangnya kesadaran masyarakat tentang kontribusi membayar pajak terutama pengguna kendaraan bermotor bagi keberlangsungan pembangunan.

Penelitian ini bertujuan untuk mengetahui proses penerapan penghapusan sanksi administrasi pajak kendaraan bermotor di Unit Pelayanan PKB dan BBN-KB Jakarta Selatan Tahun 2019 yang dilatarbelakangi masih rendahnya tingkat pemahaman masyarakat Kota Jakarta Selatan mengenai kebijakan program penghapusan sanksi administrasi Pajak Kendaraan Bermotor.

\section{LANDASAN TEORI}

\section{Implementasi Kebijakan}

Implementasi kebijakan merupakan salah satu hal yang sangat penting, hal ini dikarenakan pada implementasinya ini lah kita dapat menilai bagaimana kebijakan yang dibuat apakah baik atau tidak 
terhadap kebutuhan publik. Implementasi adalah suatu rangkaian aktifitas dalam rangka menghantarkan kebijakan kepada masyarakat sehingga kebijakan tersebut dapat membawa hasil sebaimana yang diharapkan (Agustino, 2009). Dengan mengimplementasikan sebuah kebijakan maka akan bisa dengan mudah dilakukan evaluasi apakah kebijakan yang dibuat sudah sesuai dengan yang dibutuhkan masyarakat atau perlu adanya perbaikan atau peninjauan kembali mengenai kebijakan tersebut.

Van Meter dan Van Horn dalam Winarno (2012) mengatakan bahwa implementasi sebagai tindakan-tindakan yang dilakukan oleh individu/pejabat atau kelompok-kelompok pemerintah atau swasta yang diarahkan pada tercapainya tujuan-tujuan yang telah digariskan dalam keputusan kebijaksanaan. Tindakan-tindakan keputusan menjadi pola pola operasional, serta melanjutkan usaha tersebut untuk mecapai perubahan, baik yang besar maupun yang kecil, yang diamanatkan oleh keputusan kebijakan. Secara sederhana dapat dikatakan bahwa implementasi kebijakan meliputi semua tindakan yang berlangsung antara pernyataan atau perumusan kebijakan dan dampak aktualnya. Sehingga implementasi kebijakan merupakan suatu sistem pengendalian untuk menjaga agar tidak terjadi penyimpangan dari tujuan kebijakan. Sementara itu, Widodo (2009) merumuskan batasan implementasi sebagai suatu proses mendapatkan sumber daya tambahan, sehingga dapat menghitung apa yang harus dikerjakan dan dalam proses implementasi tersebut, tidak kurang dari suatu tahap dari suatu kebijakan yang paling tidak memerlukan dua macam tindakan berurutan. Pertama, merumuskan tindakan yang akan dilakukan. Kedua, melaksanakan tindakan apa yang telah dirumuskan tadi.

Model implementasi Donald Van Meter dengan Carl Van Horn (Nugroho,2004) mengandalkan konsep implementasi kebijakan berjalan secara linear dari kebijakan publik, implementator, dan kinerja kebijakan publik. Beberapa variabel yang dimasukkan sebagai variabel yang mempengaruhi kebijakan publik adalah variabel: (1) aktivitas implementasi dan komunikasi organisasi, (2) Karakteristik dari agen pelaksana/implementator, (3) Kondisi ekonomi, sosial dan politik, (4) Kecenderungan (disposition) dari pelaksana/implementor. Dengan demikian, maka penulis menyimpulkan bahwa implementasi kebijakan merupakan tindakan-tindakan yang dilakukan oleh pemerintah, individuindividu atau kelompok swasta dengan mengerahkan seluruh sumber-sumber yang ada (dana, SDM, kemampuan organisional) setelah suatu program ditetapkan, dimana tindakan ini diarahkan untuk mencapai hasil-hasil atau tujuan-tujuan yang telah ditetapkan sebelumnya tercapai.

Penelitian ini menggunakan model implementasi milik Edward III dalam Nugroho (2004) untuk mengukur implementasi kebijakan publik. Alasan peneliti menggunakan model implementasi milik Edwards adalah karena model ini sesuai dengan keadaan atau kondisi yang ada di dalam implementasi kebijakan penghapusan sanksi administrasi pajak kendaraan bermotor di Kota Jakarta Selatan yaitu khususnya faktor komunikasi kebijakan pada saat kebijakan diimplementasikan, selanjutnya dengan mengunakan indikator faktor sumber-sumber, kecenderungan-kecenderungan dan struktur birokrasi dapat diketahui mengapa penerapan penghapusan sanksi administrasi pajak kendaraan bermotor tidak berjalan baik. Menurut Edwards, studi implementasi kebijakan adalah krusial bagi public administration (administrasi publik) dan public policy (kebijakan publik). Implementasi kebijakan adalah salah satu tahap kebijakan publik, antara pembentukan kebijakan dan konsekuensi-konsekuensi kebijakan bagi masyarakat yang dipengaruhinya. Jika suatu kebijakan tidak tepat atau tidak dapat mengurangi masalah yang merupakan sasaran dari kebijakan, maka kebijakan itu mungkin akan mengalami kegagalan sekalipun kebijakan itu diimplementasikan dengan sangat baik. Sementara itu, suatu kebijakan yang telah direncanakan dengan sangat baik, mungkin juga akan mengalami kegagalan, jika kebijakan tersebut kurang diimplementasikan dengan baik oleh para pelaksana kebijakan.

\section{Kebijakan Sunset Policy}

Pengertian Sunset policy menurut Rahayu (2009) adalah pemberian fasilitas penghapusan sanksi administrasi berupa bunga sebagaimana diatur dalam Pasal 37A Undang-Undang Nomor 28 Tahun 2007.Kebijakan ini memberi kesempatan kepada masyarakat untuk memulai kewajiban perpajakannya dengan benar. Sunset Policy telah dilakukan pada tahun 2008. Sejak Program Sunset Policy diimplementasikan sepanjang tahun 2008 telah berhasil menambah jumlah NPWP baru sebanyak 5.653.128 NPWP, bertambahnya SPT tahunan sebanyak 804.814 SPT dan bertambahnya penerimaan PPh sebesar Rp7,46 triliun. Jumlah NPWP orang pribadi 15,07 juta, NPWP bendaharawan 447.000, dan NPWP badan hukum 1,63 juta. Jadi totalnya 17,16 juta (data DJP, 2010 kuartal 1) 
Sistem pemunguan pajak yang ada di Indonesia adalah menggunakan self assesment system, dimana sistem ini merupakan suatu sistem pemungutan pajak yang memberi wewenang, kepercayaan, tanggung jawab kepada Wajib Pajak untuk memperhitungkan, membayar dan melaporkan sendiri besarnya pajak yang harus dibayar. Untuk mengatur tindakan Wajib Pajak tersebut di butuhkan sanksi pajak sebagai rambu-rambu yang diatur dalam undang-undang perpajakan yang berlaku agar pemungutan pajak dapat berjalan dengan tertib dan sesuai dengan target yang di harapkan. Dalam Undang-Undang Nomor 28 Tahun 2007, Sunset Policy adalah kebijakan pemberian fasilitas perpajakan dalam bentuk penghapusan sanksi administrasi perpajakan berupa bunga yag diatur dalam pasal 37A Undang-Undang Ketentuan Umum dan Tata Cara Perpajakan. Selanjutnya dalam Surat Edaran Direktur Jenderal Pajak Nomor SE 34/PJ/2008 tanggal 31 Juli 2008 Tentang Penegasan Pelaksanaan Pasal 37 A UU. Nomor: 28 Tahun 2008 Tentang Penegasan Pelaksanaan Pasal 37 A Undang-undang Tentang Ketentuan Umum Dan Tata Cara Perpajakan beserta ketentuan pelaksanaannya, pelaksanaan Sunset Policy diberikan penegasan sebagai berikut: (1) Konsep dasar Undang-undang perpajakan yang mengatur tentang Sunset Policy adalah sistem self assessment. Dalam sistem self assessment, Wajib Pajak diberi kepercayaan untuk menghitung, memperhitungkan, menyetor, dan melaporkan sendiri besarnya pajak yang terutang sesuai dengan ketentuan peraturan perundangundangan perpajakan. Sebagai konsekuensi pemberian kepercayaan tersebut, Wajib Pajak wajib menyampaikan Surat Pemberitahuan berikut keterangan dan/atau dokumen yang harus dilampirkan, yang telah diisi secara benar, lengkap, dan jelas. (2) Sunset Policy memberi kesempatan kepada: (a) Wajib Pajak yang telah memiliki NPWP sebelum tanggal 1 Januari 2008 untuk membetulkan SPT Tahunan PPh untuk Tahun Pajak 2006 dan/atau TahunTahun Pajak sebelumnya; (b) Wajib Pajak orang pribadi yang memperoleh NPWP secara sukarela dalam tahun 2008 untuk menyampaikan SPT Tahunan PPh untuk Tahun Pajak 2007 atau Tahun Pajak 2007 dan sebelumnya, untuk memperoleh fasilitas berupa penghapusan sanksi administrasi berupa bunga atas keterlambatan pembayaran pajak atau bunga atas pajak yang tidak atau kurang dibayar. (3) Ketentuan Sunset Policy berdasarkan Pasal 37A Undang-Undang Ketentuan Umum dan Tata Cara Perpajakan bersifat khusus dan hanya berlaku untuk jangka waktu terbatas sehingga beberapa ketentuan umum yang diatur dalam Undang-Undang Ketentuan Umum dan Tata Cara Perpajakan tidak berlaku.

Ketentuan umum yang tidak berlaku sehubungan dengan Sunset Policy seperti ketentuan yang terkait dengan: (a) pembatasan jangka waktu pembetulan SPT Tahunan PPh paling lama 2 (dua) tahun sejak berakhirnya Bagian Tahun Pajak atau Tahun Pajak; dan (b) persyaratan belum dilakukan pemeriksaan, sebagaimana diatur dalam Pasal 8 ayat (1) Undang-Undang Ketentuan Umum dan Tata Cara Perpajakan. (4) Dalam pelaksanaan Sunset Policy, Wajib Pajak diberikan kepercayaan untuk mengungkapkan seluruh penghasilan termasuk harta dan kewajiban dalam SPT Tahunan PPh WP Badan atau WP Orang Pribadi. Data dan/atau informasi yang telah diungkapkan dalam SPT Tahunan PPh WP Badan atau WP Orang Pribadi yang telah disampaikan atau dibetulkan oleh Wajib Pajak sehubungan dengan pelaksanaan Sunset Policy tidak dapat digunakan sebagai dasar untuk melakukan pemeriksaan.

\section{METODE}

Metodologi survei tergolong metode ilmiah (scientific method) yang merupakan bagian dari metodologi penelitian baik kuantitatif maupun kualitatif. Metode survey adalah studi yang sumber utama data dan informasinya diperoleh oleh responden sebagai sampel survei menggunakan kuesioner atau kuesioner sebagai alat pengumpulan data serta mempelajari prosedur dalam penarikan sampel dari suatu populasi yang tepat agar dapat digunakan untuk mengeneralisasikan keadaan populasi. Dalam penelitian ini digunakan jenis metode survei untuk penelitian evaluasi. Secara umum, metode evaluasi diterapkan pada penelitian evaluasi program sebagaimana dirumuskan dalam pertanyaan penelitian ketika program yang diterapkan telah mencapai tujuan atau mengalami kegagalan. Pencarian survei untuk tujuan evaluasi umumnya terdiri dari serangkaian studi yang lebih lengkap atau bagian dari program tertentu.

Beberapa langkah-langkah teknis sederhana namun ideal yang dapat diambil dalam metode penelitian survei adalah :

a) Merumuskan masalah penelitian dan menulis tujuan penelitian survei. 
b) Tuliskan manfaat penelitian survei dengan cara akademik praktis. Jika diperlukan, menentukan konsep dan hipotesis penelitian.

c) Mengumpulkan informasi dari hasil studi sebelumnya yang terkait.

d) Menentukan sampel penelitian dilakukan berdasarkan accidental sampling atau jumlah responden yang datang ke lokasi penelitian (BPRD Provinsi DKI Jakarta)

e) Membuat angket atau kuesioner, digunakan alat bantu aplikasi google form.

f) Pengumpulan data, termasuk pernyataan untuk asisten peneliti yang mengumpulkan data penelitian, dilanjutkan dengan memproses dan menganalisis data secara manual atau dengan komputer.

Mendukung pengungkapan fenomena-fenomena tersebut di atas, peneliti menggunakan studi kepustakaan untuk mengumpulkan data-data yang relevan melalui sumber terpercaya, baik itu melalui buku, jurnal, artikel media masa, dan internet. Data dalam penelitian ini akan melalui empat tahapan analisis Sugiyono (2015) yakni pengumpulan data, reduksi data, penyajian data, dan penarikan kesimpulan secara induktif.

\section{HASIL DAN PEMBAHASAN}

\section{Kebijakan Penghapusan Sanksi Administrasi Pajak (Sunset-Policy)}

Dasar hukum penghapusan sanksi administrasi Pajak Kendaraan Bermotor (PKB), Bea Balik Nama (BBN) kendaraan bermotor serta penghapusan sanksi administrasi tercantum pada Peraturan Gubernur Nomor 34 tahun 2017 Tentang Tata Cara Pengurangan atau Penghapusan Sanksi Administasi Pajak Daerah sebagaimana telah di ubah Peraturan Gubernur Nomor 3 Tahun 2018. Hal ini mengindikasikan bahwa Pajak kendaraan bermotor merupakan penyumbang terbesar dalam Pendapatan Asli Daerah (PAD) hal ini dikarenakan pajak kendaraan bermotor mempunyai beberapa keunggulan dibandingkan dengan sumber pajak daerah lainnya diantaranya bersifat elastis, biaya pengumpulan yang relatif rendah, administrasi yang mudah melalui sistem komputerisasi, tingkat kebocoran rendah dan adil (Mahmudi, 2010). Dalam pemungutan pajak kendaraan bermotor dikenal dengan istilah penerapan Official Assessment System, artinya dalam penentuan nominal dan pelaporan objek pajak dilakukan oleh instansi atau dinas terkait.

Pemerintah Provinsi (Pemprov) DKI Jakarta menghapus sanksi atau denda atas tiga jenis pajak, yakni denda Pajak Kendaraan Bermotor (PKB), sanksi administrasi Bea Balik Nama Kendaraan Bermotor (BBNKB), serta sanksi administrasi Pajak Bumi dan Bangunan Pedesaan dan Perkotaan (PBB-P2). Denda PKB adalah denda yang harus dibayar pemilik kendaraan atas keterlambatan membayar pajak motor atau mobil. Tentunya melewati batas waktu yang sudah ditentukan di Surat Tanda Nomor Kendaraan (STNK). Ada yang telat hitungan hari, sebulan, dua bulan, bahkan lebih dari setahun. Bea balik nama kendaraan bermotor adalah pajak atas penyerahan hak milik kendaraan bermotor karena jual beli, tukar menukar, atau warisan. Sedangkan sanksi administrasi PBB-P2, yaitu denda atas keterlambatan pembayaran pajak bumi dan bangunan yang dimiliki atau dikuasai, seperti tanah, rumah, dan properti lainnya.

Dalam meningkatkan kesadaran wajib pajak dalam membayar pajak, Gubernur DKI Jakarta melimpahkah kewenangan untuk melaksanakan kebijakan retribusi pajak daerah melalui Badan Pajak dan Retribusi Daerah (BPRD) Provinsi DKI Jakarta. Masyarakat mengenal penghapusan sanksi administrasi pajak kendaraan dengan istilah "pemutihan". Kebijakan pemutihan Tahun 2019 dilakukan mulai tanggal 16 September 2019 sampai dengan 30 Desember 2019. Kebijakan pemutihan ini dilakukan dengan tujuan untuk meningkatkan kesadaran masyarakat terutama yang termasuk dalam objek pajak kendaraan dalam membayar pajak kendaraan bermotor, agar bisa menghidupkan kembali objek pajak yang selama ini tidak aktif serta menertibkan data kepemilikan kendaraan secara administratif. Selain itu juga kebijkan ini dikeluarkan karena untuk mengejar target penerimaan Pendapatan Asli Daerah dari sektor pajak kendaraan bermotor.

Pemprov DKI Jakarta menghapuskan denda pajak kendaraan bermotor (PKB) dan bea balik nama kendaraan bermotor (BBNKB) untuk meningkatkan pendapatan negara bukan pajak (PNBP) menjelang akhir 2019. Samsat Jakarta Selatan sendiri menargetkan pajak PKB dan BBNKB pada 2019 ini sebesar Rp 3,4 triliun. Untuk bisa mencapai proses pencapaian target tersebut pemerintah provinsi dengan wewenang otonomi daerahnya mengeluarkan kebijakan penghapusan Sanksi Administrasi 
(Sunset Policy jilid II). Namun menurut sumber dari www.oto.detik.com (Jum'at, 20 September 2019) bahwa sampai bulan Desember 2019 jumlah tunggakan pajak kendaraan bermotor di Kota Jakarta Selatan mencapai 15 Milyar di mana di akhir Tahun 2019 realisasi penerimaan pajak kendaraan bermotor PKB dan BBN di Jakarta Selatan sebesar Rp 115.917.771.730,- terjadi penurunanan sebesar Rp 108.247.742.466,- artinya masih tunggakan pajak kendaran bermotor sekitar 7,5 Milyar.

Kebijakan pemutihan ini memiliki hubungan kausalitas dengan penerimaan pajak kendaraan bermotor, dimana kebijakan pemutihan ini diberikan kepada masyarakat untuk meringankan wajib pajak (Ekasari dan Akbari, 2017). Walaupun dalam kebijakan pemutihan ini hanya berupa penghapusan sanksi administrasi artinya wajib pajak tetap harus membayar besaran pokok pajak tersebut, akan tetapi masyarakat kurang responsif menyambut kebijakan ini. Artinya diharapkan masyarakat dapat mengikuti kebijakan pemutihan ini, terlihat dari meningkatnya jumlah tunggakan objek pajak pada masa pemutihan itu diberlakukan. Hal tersebut tentunya berdampak pada keberhasilan peningkatan penerimaan pajak kendaraan bermotor.

Permasalahan perpajakan yang umumnya berdampak pada rendahnya kepatuhan pajak, rendahnya penerimaan pajak, hingga rendahnya kapasitas lembaga administrasi perpajakan.Tahun ini dimulai dengan revisi Rancangan Undang-Undang (RUU) Ketentuan Umum dan Tata Cara Perpajakan (KUP), kemudian di tahun-tahun berikutnya akan dilanjutkan dengan RUU Pajak Pertambahan Nilai Barang dan Jasa (PPN), Pajak Penghasilan (PPh), dan Pajak Bumi dan Bangunan (PBB). Dalam revisi mengenai UU KUP tahun ini, pemerintah akan menambahkan aturan mengenai tax amnesty atau pengampunan pajak (Pasca, 2020) Artinya secara sederhana dari tax amnesty adalah pengampunan pajak, yaitu adanya penghapusan pajak bagi Wajib Pajak yang menyimpan dananya di luar negeri dan tidak memenuhi kewajibannya dalam membayar pajak dengan imbalan menyetor pajak dengan tarif lebih rendah. Dengan dilakukannya tax amnesty ini, diharapkan para pengusaha yang menyimpan dananya di luar negeri akan memindahkan dananya di Indonesia dan menjadi Wajib Pajak baru yang patuh sehingga dapat meningkatkan pendapatan pajak negara.

Latar belakang pemerintah mengajukan kebijakan tax amnesty tahun ini: Yang pertama kebijakan tax amnesty harus dilihat sebagai kebijakan ekonomi yang bersifat mendasar karena dari sisi pajaknya sendiri, dengan adanya tax amnesty maka ada potensi penerimaan yang akan bertambah dalam APBN baik di tahun ini atau tahun-tahun sesudahnya yang akan membuat APBN lebih sustainable. APBN lebih sustainable dan kemampuan pemerintah untuk spending atau untuk belanja juga semakin besar sehingga otomatis ini akan banyak membantu program-program pembangunan tidak hanya infrastruktur tapi juga perbaikan kesejahteraan masyarakat. Namun demikian, tidak dapat dipungkiri bahwa tax amnesty merupakan sebuah isu yang kontroversial dalam dunia perpajakan (Ngadiman dan Huslin, 2015). Asumsi kontroversial yang mendasari tax amnesty adalah dihapuskannya pokok pajak, sanksi administrasi dan/atau pidana pajak atas ketidakpatuhan yang telah dilakukan oleh wajib pajak di masa lalu demi peningkatan kepatuhan di masa yang akan datang. Di satu sisi, tax amnesty dipandang sebagai jalan keluar untuk meningkatkan penerimaan di masa yang akan datang karena tax amnesty memberikan kesempatan kepada wajib pajak untuk masuk atau kembali ke dalam sistem administrasi perpajakan yang berdampak pada peningkatan penerimaan di masa yang akan datang. Namun, di sisi lain, tax amnesty dapat mengurangi tingkat kepatuhan di masa yang akan datang jika wajib pajak tetap mempertahankan ketidakpatuhannya setelah program tax amnesty berakhir sembari berharap akan adanya program tax amnesty di masa yang akan datang. (Enste dan Schneider, 2015)

\section{Internalisasi Program Sunset Policy}

Pemberian Sunset policy merupakan upaya pemerintah menarik dana masyarakat yang selema ini parkir di perbankan negara lain. Sunset policy diberikan kepada mereka yang selama ini tidak membayar dengan benar (Mardiasmo, 2009). Kendati demikian, kebijakan ini masih perlu diselaraskan dengan instansi penegak hukum lain serta dibahas dengan Dewan Perwakilan Rakyat (DPR). Hal ini terkait pihak-pihak yang dinilai pantas menerima penghapusan sanksi. Misalnya, pelanggar pidana pajak boleh mendapatkan pengampunan jika tidak terkait dengan korupsi. Di mana Pemerintah pada 2008 lalu pernah melakukan sunset policy, yakni penghapusan sanksi administrasi perpajakan berupa bunga. Ketika itu, pemerintah berhasil menghimpun dana sekitar Rp 5,5 triliun dari program tersebut. 
Upaya pemerintah untuk mengejar potensi penerimaan pajak melalui kebijakan sunset policy harus dilakukan dengan persiapan yang memadai. Berdasarkan pengalaman tahun 2008 saat kebijakan serupa juga dijalankan, pemerintah membutuhkan waktu setahun lebih untuk melakukan persiapan. Dari hasil penelitian dapat diketahui bahwa kepatuhan Wajib Pajak sebelum diberlakukannya Sunset Policy masih relatif rendah, dibandingkan dengan masa setelah berlakunya Sunset Policy yang ternyata cenderung meningkat, hal ini dapat dilihat dari adanya peningkatan jumlah WP, jumlah setoran pajak, berkurangnya Surat Ketetapan Pajak dan meningkatnya Tax Ratio, dan kepatuhan itu tentu harus tetap ditingkatkan dengan cara : Pembenahan administrasi pajak, perbaikan pelayanan, penyuluhan secara sistimatis dan berkesinambungan kepada Wajib Pajak serta adanya penegakan hukum, dapat dikatakan kebijakan sunset policy tidak membuat animo masyarakat untuk taat membayar pajak meningkat.

Kebijakan sunset policy dan tax amnesty merupakan suatu kebijakan yang bertentangan (Prananjaya, 2018). Akan tetapi dua kebijakan ini akan berhasil jika saling mendukung. Reinforcement theory menjelaskan menjelaskan mengenai hubungan kausalitas atas perilaku dengan adanya suatu hukuman dan kompensasi. Dalam hubungannya dengan penelitian ini, teori ini dapat dikaitkan dengan kepatuhan pajak dimana pemerintah mengeluarkan suatu kebijakan atau peraturan perpajakan yang berkaitan dengan sanksi pajak dan adanya insentif berupa kebijakan Tax Amnesty. Sanksi pajak (sunset policy) dapat memotivasi para wajib pajak terhadap kepatuhan pajak dalam memperhitungkan dan membayarkan pajak. Dengan adanya sanksi pajak maka para wajib pajak akan termotivasi untuk selalu patuh terhadap pajak. Hal ini dikarenakan apabila Wajib Pajak tidak patuh dalam membayarkan atau memperhitungkan pajaknya maka akan diberikan suatu hukuman (punishment) baik berupa sanksi administrasi atau pidana yang akan memberikan efek jera kepada Wajib Pajak. Sama halnya dengan sanksi pajak, insentif berupa kebijakan tax amnesty juga akan memotivasi para Wajib Pajak untuk selalu patuh dalam membayarkan dan memperhitungkan pajak. Dalam kebijakan Tax Amnesty kali ini, apabila Wajib Pajak pada tahun sebelumnya pernah melakukan kecurangan dalam perhitungan pajak (melakukan pengecilan pajak), dengan mengikuti program Tax Amnesty maka pajak yang seharusnya terutang dan sanksi administrasi perpajakan para Wajib Pajak akan terhapus. Dengan adanya hal tersebut para wajib pajak tidak ingin membuat suatu kesalahan (tidak patuh pajak) lagi. Dapat disimpulkan bahwa berdasarkan Reinforcement Theory, individu dapat terangsang untuk mengubah internalisasi perilakuya menjadi lebih baik atau sesuai dengan yang diharapkan berupa pemberian motivasi baik berupa kompensasi maupun hukuman.

Adanya peraturan yang dikeluarkan oleh berbentuk sunset policy agaknya "menggugah" animo masyarakat khususnya wajib pajak kendaraan bermotor di Jakarta Selatan untuk mulai menangkap sinyal yang diberikan pemerintah di dalam turut serta dalam program pajak. Saat ini apabila wajib pajak mengurus berkas BBN dan PKB telah disediakan informasi kebijakan sanksi pajak namun masih dalam lingkup skala terbatas, biasanya hanya di bulan tertentu / menjelang akhir tahun. Meskipun demikian tampaknya masyarakat masih enggan untuk mengeluarkan sedikit waktu untuk memanfaatkan kebijakan sansi administrasi tersebut bahkan keterlambatan membayar pajak tidak beresiko denda yang besar. Banyak usaha lain mulai dilakukan melalui sosialiasi maupun edukasi akan program sunset policy melalui berbagai macam brosur ataupun stiker yang dipasang di dekat area kasir. Meskipun belum terlihat hasil nyata tetapi paling tidak ada internalisasi sikap dalam mensukseskan program pemerintah tersebut.

Apabila dikaji lebih jauh tentang peran dari wajib pajak kendaraan bermotor dalam ketaatan dan memanfaatkan insenti pajak (sunset policy) ini, di Kota Jakarta Selatan dilakukan hasil survei yang periode Bulan September-Desember 2019 berhasil mewawancara 210 responden dari 300 responden. Mereka semua warga Kota Jakarta Selatan yang sedang mengurus PKB dan BBN kendaraan bermotor di Kantor Samsat Jakarta Selatan dan menjadi tolok ukur penelitian dimana responden tersebut dipilih secara acak melalui alat bantu aplikasi google-form. Responden yang menyatakan sikap responsif terhadap kebijakan sunset policy mencapai mencapai 88,5 persen (dari hasil rekapitulasi survey). Adapun alasan dari responden tersebut dapat diuraikan beberapa kriteria sebagai berikut:

a. 22,8\% menyatakan bahwa responden di Kota Jakarta Selatan sudah mengetahui tentang penghapusasn sanksi administrasi kendaraan bermotor, (indikator standar kebijakan).

b. 47,9 \% menyatakan Responden setuju terhadap kebijakan penghapusasn sanksi administrasi kendaraan bermotor namun mereka belum memanfaatkannya (indikator sasaran kebijakan) 
c. $8,7 \%$ Responden menyatakan belum pernah mendapatkan penyuluhan tentang sosialisasi penghapusasn sanksi administrasi kendaraan bermotor (indikator sumber daya)

d. 5,7 \% Responden menyatakan bahwa penghapusasn sanksi administrasi kendaraan bermotor, dinilai kurang efektif, karena hanya mejangkau kepemilikan kendaran mobil-mobil mewah (indikator karakteristik organisasi)

e. 2,2\% Responden menyatakan bahwa penghapusasn sanksi administrasi kendaraan bermotor sudah dimanfaatkan wajib pajak, hal ini dikarenakan masih adanya sikap pegawai pajak yang bersedia membantu responden (indikator lingkungan sosial)

f. Hanya sebagian kecil 1,2\% responden yang menyatakan tidak mengetahui tentang kebijakan penghapusasn sanksi administrasi kendaraan bermotor dan sisanya dipengaruhi oleh faktor lainnya.

Dari hasil survey tersebut dapat diketahui bahwa kesadaran masyarakat untuk memanfaatkan kebijakan penghapusasn sanksi administrasi kendaraan bermotor belum maksimal masih meretas berbagai masalah, sebagaimana hasil rekapitulasi penelitian. Hal ini ditandai pula masih rendahnya tingkat penyuluhan tentang sosialisasi penghapusasn sanksi administrasi kendaraan bermotor di Kota Jakarta Selatan. Sehingga perlu adanya upaya-upaya yang harus dilakukan untuk menjaga dan meningkatkan kepatuhan Wajib Pajak setelah berakhirnya Sunset Policy antara lain adalah dengan Pembenahan Administrasi Pajak (Tax Administration) dengan sebaik-baiknya sehingga menjadi instrumen yang mampu bekerja secara efektif dan efisien, hal ini adalah untuk menjawab keluhan Wajib Pajak yang masih menganggap rumit sistim perpajakan yang berlaku. Selain itu peran penyuluhan secara sistimatis dan berkesinambungan kepada Wajib Pajak, supaya Wajib Pajak faham terhadap hak dan kewajibannya, sehingga kemudian muncul kepatuhan dalam diri Wajib Pajak itu sendiri, sehingga otomatis kebijakan Sunset Policy bisa berhasil meningkatkan kepatuhan Wajib Pajak.

\section{KESIMPULAN}

Badan Pajak dan Retribusi Daerah (BPRD) Provinsi DKI Jakarta pada akhir Tahun 2019 memprediksi dari 3,1 juta kendaraan roda dua dan sekitar 748,5 ribu unit mobil yang menunggak pembayaran pajak PKB dan BBN, jika di total tunggakan tersebut mencapai angka 1,18 triliun. Penelitin ini menemukan tunggakan pajak kendaraan bermotor di Kota Jakarta Selatan sampai akhir Bulan Desember 2019 mencapai 15 Milyar dengan realisasi penerimaan pajak kendaraan bermotor PKB dan BBN sebesar Rp 115.917.771.730,- terjadi penurunanan sebesar Rp 108.247.742.466,artinya masih ada tunggakan pajak kendaran bermotor sekitar 7,5 Milyar. Walaupun dalam kebijakan pemutihan ini hanya berupa penghapusan sanksi administrasi artinya wajib pajak tetap harus membayar besaran pokok pajak tersebut, akan tetapi kenyataannya masyarakat di Kota Jakarta Selatan kurang responsif menyambut kebijakan ini. Pernyataan ini muncul dari hasil survey dari responden yang menyatakan sikap responsif terhadap kebijakan sunset policy mencapai mencapai 88,5\%, diantaranya $47,9 \%$ menyatakan responden setuju terhadap kebijakan penghapusasn sanksi administrasi kendaraan bermotor namun mereka belum memanfaatkannya.

\section{DAFTAR PUSTAKA}

Adiyanta, F. S. (2018). Kebijakan Penghapusan Sanksi Administrasi Perpajakan sebagai Stimulus Peningkatan Penerimaan Negara dari Sektor Pajak (Studi Evaluatif Normatif Kebijakan Perpajakan Nasional). Adminitrative Law \& Governance Journal, 62-78.

Agustino, L. (2009). Dasar Dasar Kebijakan Publik. Bandung: Alfabeta.

Ekasari, Luh Dina. dan Akbari, Febrian. (2017). Tingkat Efektivitas Penerapan Pemutihan Pajak Kendaraan Bermotor Terhadap Peningkatan Penerimaan Pajak Daerah (Studi Pada Unit Pelaksana Teknis Dinas Pendapatan Provinsi Jawa Timur Malang Utara dan Batu Kota). OPTIMA; Jurnal Ilmiah Agribisnis, Ekonomi dan Sosial, 1(2), 1-10.

Mahmudi. (2010). Manajemen Kinerja Sektor Publik. Yogyakarta: UPP AMP YPKN.

Mardiasmo. (2009). Perpajakan Indonesia. . Edisi Revisi. Yogyakarta: Andi. 
Ngadiman dan Daniel Huslin. (2015, Mei). Pengaruh Sunset Policy, Tax Amnesty, dan Sanksi Pajak terhadap Kepatuhan Pajak (Studi Empiris di Kantor Pelayanan Pajak Pratama Jakarta Kembangan). Jurnal Akuntansi, XIX(2), 225-241.

Nugroho, R. T. (2004). Kebijakan Publik, Formulasi, Implementasi, dan Evaluasi. Jakarta: PT Elex Media Komputindo.

Prananjaya, K. P. (2018). Dapatkah Sanksi Pajak Dan Tax Amnesty Memitigasi Tindakan Ketidakpatuhan Pajak? Bukti Eksperimen di Indonesia. BAKI Berkala Akuntansi dan Keuangan Indonesia, 23-45.

Rahayu, S. K. (2009). Perpajakan Indonesia Konsep Aspek Formal. Yogyakarta: Graha Ilmu.

Scneider, Friedrich dan Enste, Dominik H. (2015). Shadow Economies: Size, Causes and Consequences. Journal of Economic Literature, XXXVIII, 15-31.

Sugiyono. (2015). Metode Penelitian Kuantitatif Kualitatif dan Research and Development. Bandung: Alfabeta.

Sunarta, D. A. (2017). Implementasi Peraturan Menteri (Permen) Keuangan No. 29 tahun 2015 Tentang Penghapusan Sanksi Administrasi Pajak (Analisis Etika Manajemen Syariah). IAIN Parepare Repository, 1-11.

Syafitri, A. (2016). Implementasi Peraturan Menteri Keuangann (PMK) Nomor 91/PMK.03/2015 Tentang Pengurangan dan Penghapusan Sanksi Administrasi di KPP Pratama Pekanbaru Senapelan. JOM FISIP, 3(2), 1-13.

Widodo, J. (2009). Analisis Kebijakan Publik Konsep dan Aplikasi Analisis. Malang: Bayumedia Publishing.

Winarno, B. (2012). Kebijakan Publik: Teori dan Proses Edisi Revisi. Yogyakarta: Media Presindo.

Internet: Tax Amnesty Diposting oleh : Yelsha Dwi Pasca (2020) http://id.stie-stmy.ac.id/berita-174tax-amnesty.html?fb_comment_id=1438593452822531_1477990212216188 